\title{
Wetlands of recent Dutch embankments
}

\author{
W. Joenje ${ }^{1} \&$ B. Verhoeven ${ }^{2}$ \\ ${ }^{1}$ Agricultural University, Bornsesteeg 69,6709 PD Wageningen, The Netherlands \\ ${ }^{2}$ Waterkant 83, 8307 AZ Ens, The Netherlands
}

Key words: wetland, polder, drainage, desalination, colonization, vegetation-succession, groundwater regimes, meso-series

\begin{abstract}
Wetlands of new embankments are characterized with respect to soil and hydrological regime and the processes of desalination and vegetation succession. Soil- and height gradients, the lack of local drainage and the generally low nutrient content provide conditions for dynamic mesoseries (groundwatertable low in summer, saturated in winter) and locally for stable mesoseries (relatively high in summer, saturated in winter).

Relations between vegetation and herbivores (geese, ducks, cattle) are discussed.
\end{abstract}

\section{Introduction}

The skill of coastal engineering has evolved in The Netherlands over at least a millennium. The dikes and dams, sluices and mills which protect against flooding of the land drained from sea and swamp, are backbone structures in the Dutch lowlands, which indeed, are predominantly man-made.

Following previous storm floods the dikes have been repaired and often increased in height. However, the storm surge of 1953 triggered a new approach: on some places long stretches of dikes were enforced and heightened, but elsewhere new high dams, huge sluices and sophisticated stormsurge barriers have been constructed in the estuaries of the southwest and the north. This shortening of the coastline eliminated the most valued parts of the natural coastal wetlands: the estuaries, their mudflats and shallows and gradients in salinity and nutrients.

However much the extinction of the tidal lands has been felt as a loss, parts of the newly formed landscapes have not been used as farmland and offer a rich variety of spontaneous, 'natural' developments. Gradually the outstanding value of these newly embanked wetlands has been formally recognized; substantial areas have received the status of nature reserve and proper naturemanagement schemes are being developed with increasing input of local and national experiences.

Stimulated by the Dutch examples and technology, neighbouring countries have also hardly left alone any estuary or free discharging river along the North Sea coasts. The related losses of natural habitats are partly counterbalanced by the development and careful management of new wetlands. Indeed, the whole chain of new habitats which has been created along the North Sea coasts presents a major ecological feature.

The knowledge of natural succession obtained in these new territories over several decades, and experience of habitat construction have promoted the recent ideas on, and applications of, "nature technique": the habitat construction de novo and 
the subsequent management of these natural successions according to formulated aims. Also outside the new embankments these ideas have now developed to become part of nature conservation strategies in a much wider sense.

In this chapter the soil- and hydrological processes in the new wetlands of recent Dutch embankments are summarized and related to the development of plant species and communities. The descriptions and conclusions often hold for other areas outside The Netherlands on the coasts of the North Sea.

\section{The polder concept}

A polder is considered to be an area whose hydrology has been made independent from the surrounding watertable. This definition usually is restricted to areas which have been reclaimed mainly for agricultural purposes. Within this view falls a wide variety of lowlands such as coastal polders, peat and swamp embankments and reclaimed lakes. However, in the context of this paper, stretches of water with controlled water table, such as dammed rivers and reservoirs and the holms and watermeadows belonging to them, can all be included under the heading "polder", although the polder status of such areas may be quite arbitrary.

The first human inhabitants in the Netherlands lived on high sites, like beach-ridges, creek- and river levees and outcrops of pleistocene deposits. Later, man-made mounds safeguard their dwellings from flooding. At the time the local population started to protect their grounds on the high saltmarsh against the sea by means of dikes, the first coastal polders came into being. During low tide the excess water was drained off through flapgates, but the rise of the sea level and the subsidence of the land increased the need for lifting or pumping devices.

The large and relatively elevated inland peat and peat-on-clay areas became also cultivated. Small streams as well as the main rivers, provided a certain drainage. But here too the drainage caused subsidence (by mineralization and compaction, enhanced by peat digging) and this in- creased pressure for the construction of pumping installations.

A special category of polders consists of reclaimed lakes (443 'droogmakerijen' (in Dutch), comprising 240 former natural lakes and 203 lakes originating from peat excavation), which cannot be drained without mills (Schultz 1987).

The excess water in polders and 'droogmakerijen' is often lifted to an intermediate reservoir system, (the 'boezem') from which it is sluiced or pumped into a river or the sea. Figure 1 shows the principal categories of land protected against flooding in the Netherlands.

Drainage was always a cumbersome activity, so in most polder-like areas wetlands were common. Nowadays modern pumping stations allow a deep and constant drainage which eliminates many wetland conditions. But in the newest coastal embankments large wetlands form part of the project. This text deals only with the latter wetlands and derives examples in particular from the Lake Grevelingen and the Lauwersmeer (Fig. 1).

For a description and ecological survey of the effects on the flora and vegetation of embankments and drainage in the southwest of the Netherlands, the reader is referred to Beeftink (1975).

\section{Coastal embankments}

The builders of the oldest coastal polders avoided the embankment of low lying areas: there the tidal movement hampered dike construction and drainage by gravity of such low patches was difficult. Wetlands formed by the closing of narrow creeks lost their natural value by deeper drainage or disappeared by landfill. However, these polders have a variety of wetlands originating from peat excavation for salt making and clay digging for dike repair.

Later on the closing of somewhat wider tidal gaps became feasible and sandy and muddy creek beds were transformed into valuable brackish or fresh wetland strips after embankment. In the second half of this century this development led to the enclosure of large sea arms and estuaries, dictated by the greater safety requirement against 

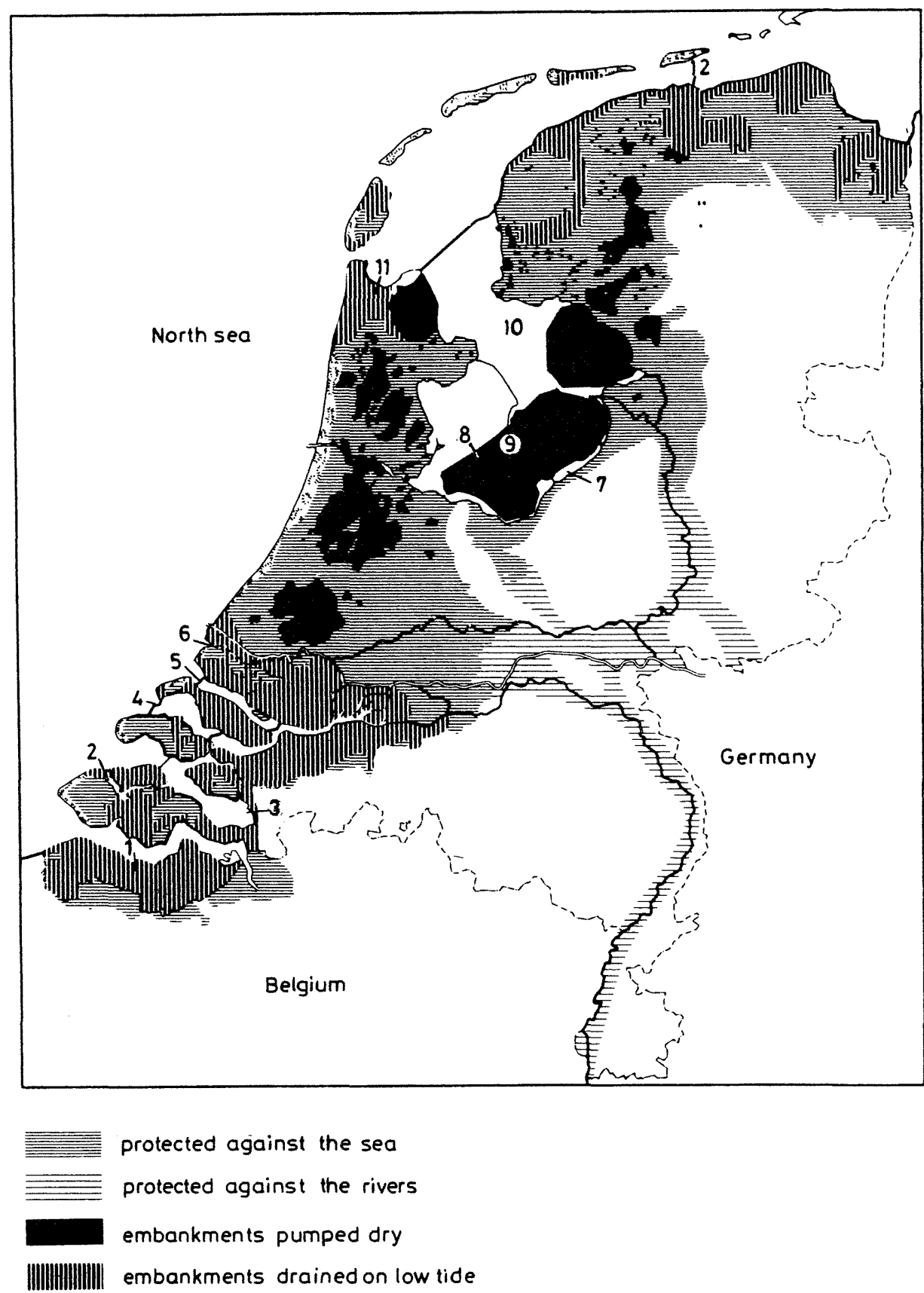

Fig. 1. Areas in The Netherlands protected against flooding (after Schultz, 1987). (Key: 1. Braakman; 2. Veerse Meer; 3. Markiezaatsmeer; 4. Grevelingen Meer; 5. Haringvliet; 6. Brielse Meer; 7. Border Lakes; 8. Oostvaarders Plassen; 9. Flevo polder: 10. IJsselmeer: 11. Amstelmeer; 12. Lauwersmeer.)

stormfloods and the improvement of the drainage of the hinterland, rather than by the wish to gain new land.

In these recently embanked areas the surface of the land is often equalled by the water surface and it is in these new polders where large areas of wetlands are formed. Unlike in older polders, the water quality is only partially determined by the 
precipitation and the drainage water from the polder itself, because the bulk of the water received in its reservoir lake stems from far larger catchment areas in the predominantly agricultural hinterland.

\section{The abiotic environment}

Generally the terrestrial part of the new embankment comprises at least two morphologically different areas: vegetated land of higher elevation (former saltmarshes, in Dutch 'schorren' or 'kwelders') and the void or scarcely vegetated lower areas (tidal flats, in Dutch 'slikken' or 'wadden'). The higher marshes are usually reclaimed for agricultural use; they are too dry to become a wetland. The lower flats however are subjected to the natural fluctuations governed by the new hydrological regime (target-polderlevels, precipitation and drainage) replacing the tide. They often remain significant as wetlands, provided that their hydrology meets a wetland definition and the land use does not interfere with natural developments, as does military use, recreation or agriculture.

The embanked waters may remain saline (Grevelingen), change to brackish (Veerse Meer, Braakman) or fresh conditions (Lauwersmeer, Amstelmeer, Haringvliet, Brielse Meer, Markiezaatsmeer and the IJsselmeer with its Borderlakes and - within the Flevopolder - the Oostvaardersplassen (Fig.1)). Summer and winter water levels may be different. In some embankments (Lauwersmeer, Braakman) the contents of the lake are replaced several times during winter by inflow from the hinterland; in others the level is maintained through supply by precipitation and drainage from the surrounding land and adjusted by in- and outlets (Grevelingen). In the saline Veerse Meer the unusual conditions of a high summer- and a low winterwatertable are now being reconsidered.

The sediments, generally rich in lime vary from rather fine grained sands to clay. Almost all soil properties, be it physical or chemical, are correlated with the amount of lutum (particles $<2 \mu \mathrm{m}$ ), at least within a certain geographical area and

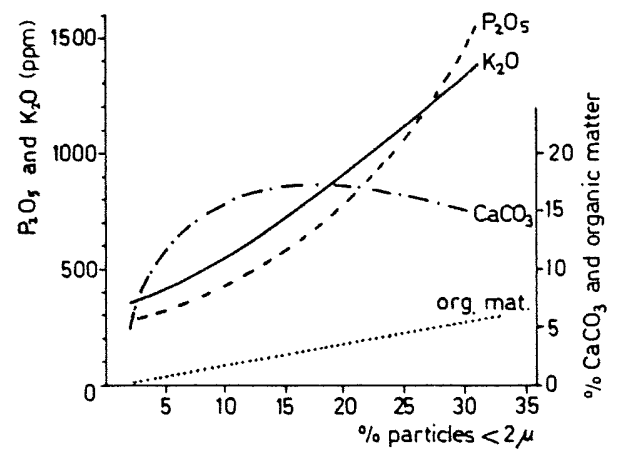

Fig. 2. The relationship between the amount of $\mathrm{P}_{2} \mathrm{O}_{5}, \mathrm{~K}_{2} \mathrm{O}$. $\mathrm{CaCO}_{3}$, organic matter and the lutum content in marine coastal sediments (Verhoeven, 1952).

environment (Fig. 2). A fresh silt shows a higher pore volume than an older deposit; a vegetated mud contains more organic matter per g of lutum, than a bare mud. In samples with the same lutum content the lime content in Zeeland (southwest) is as a rule higher than in the Wadden Sea area.

After drainage the clayey sediments which are no longer or only rarely inundated, dry and shrink, resulting in crack formation and subsidence. The pore volume decreases from $60-80 \%$ to $60-65^{\circ}$ o in the saltmarsh and $40-45 \%$ in the older polders. Although the total pore space diminishes, the number of wide pores increases; hence the aeration improves and in a complex of chemical (oxidation-)reactions the soil 'ripens.' This process of initial soil formation is well documented from the IJsselmeer polders (Zuur, 1961).

Percolating precipitation water washes the salt downwards. The leaching rate depends mainly upon the amount of water passing through the soil, although the soil moisture characteristics play a part too. The precipitation of only one average winter, as far as available for downward passage, may amount to $300 \mathrm{~mm}$ (for a sandy soil) and will be sufficient for the complete leaching of salt from the rhizosphere. However, in conditions of impeded drainage (high ground watertable, impervious layers) this may take several decades.

Capillary rise of groundwater during the summer (up to $150 \mathrm{~mm}$ in wetland conditions) may resalinize the surface layers. More complicated 
salinity patterns in the riparian zone may develop, either in relation to seepage of deeper groundwaters, or, in contrast, to an influx of lake water (fresh or saline) into the border zone (Fig. $3 \mathrm{a}, \mathrm{b}$ ). The patterns of salt and water movements pro-
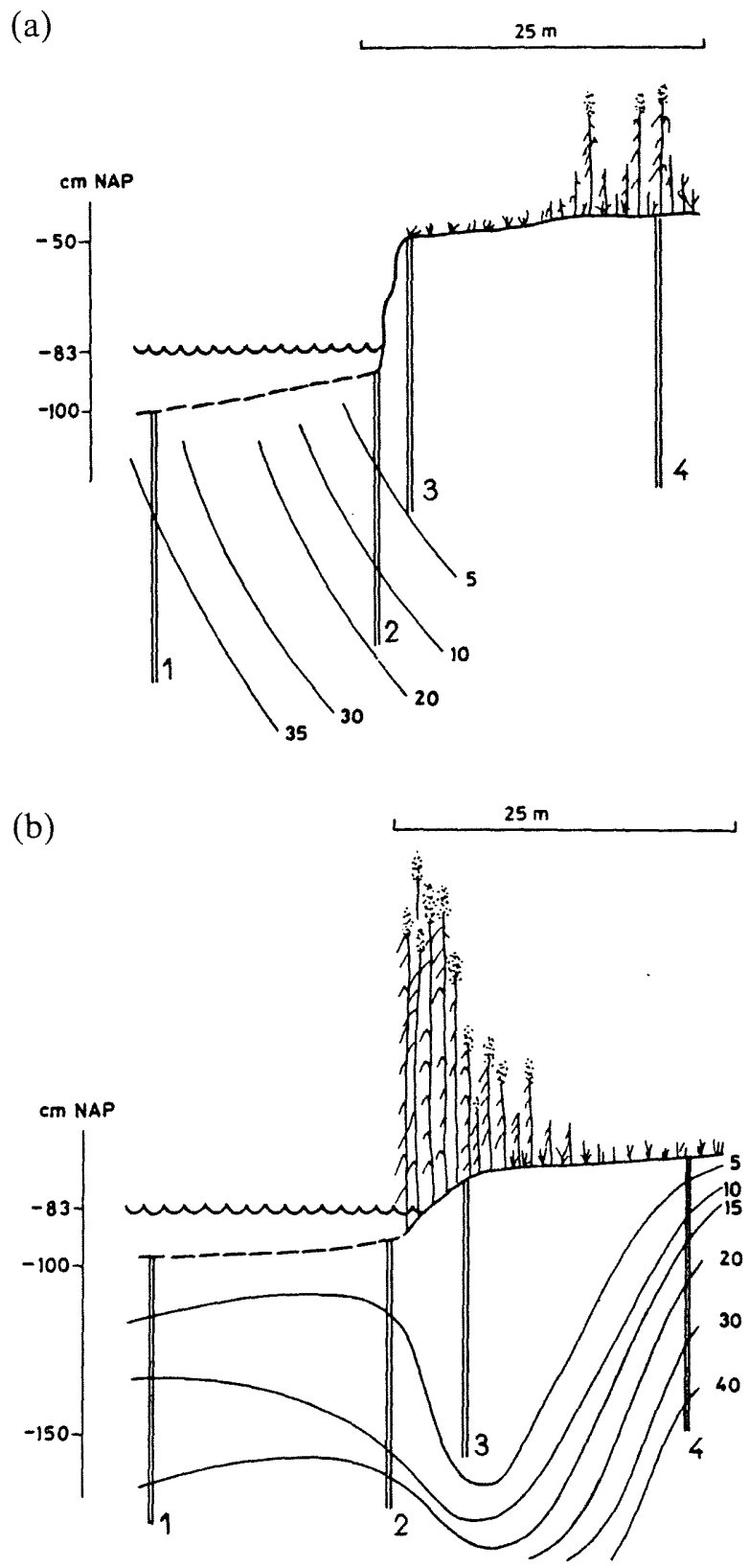

Fig. 3. Isohalines ( $\mathrm{g} \mathrm{l}^{-1}$ soil moisture) in the borderzone of the (fresh) reservoir in the Lauwerszeepolder, 10 years after the enclosure (after Pot, 1983); (a) a high and well-drained sandflat (b) a low, silty sandflat with impeded drainage. vide the predominant factors for the development of the vegetation.

Excluding the sands poor in lutum, the young marine sediments are moderately rich in phosphorus and potassium, although the $\mathrm{K}$ content tends to decrease with desalination. Part of the organic nitrogen, especially from decaying organisms, is readily mineralized. The $\mathrm{NH}_{3}$ and $\mathrm{NO}_{3}$ produced is lost in the early years by leaching and denitrification or accumulated in new plant and animal biomass (Bakker, 1958; Van Schreven, 1965).

Below the coarser sandflats a freshwater lens can be formed within a few years, as is described for the Braakman (Smit \& Visser 1987) and the Lauwersmeer (Fig. 3a) and a fresh seepage border zone is maintained (Fig. 4a, b). In siltier sands the summer evapotranspiration causes a concave groundwater table far below the level of the lake and as a consequence the lake water seeps into the border area; a possible result of this process is depicted in Fig. 3b. This process may be reversed in winter. A remarkable phenomenon is reported from the Stampersplaat (Grevelingen), where a freshwater lens was formed to a depth of $10 \mathrm{~m}$ in 8 years, which extends under the lake (Fig. 4b), in this way enabling reed (Phragmites australis) to grow in the saline border zone (Visser et al., 1987).

\section{Succession on embanked tidal flats}

The natural succession of a desalinating former tidal landscape has been documented on several occasions, especially in the Netherlands (a.o. Feekes 1936, 1943; Beeftink 1971, Joenje 1978). The process is described in some detail using data from the Lauwerszee-polder (Joenje, 1978).

\section{Abiotic conditions and changes}

The estuary of the Lauwerszee (9100 ha) was embanked in May 1969 and the tidal channels changed into a reservoir lake of some 2,100 ha, with a summer level at NAP (Dutch Ordnance Level) $-0.83 \mathrm{~m}$, enlarged by $200 \mathrm{ha}$ at the winter level of NAP $-0.93 \mathrm{~m}$. The average depth of 

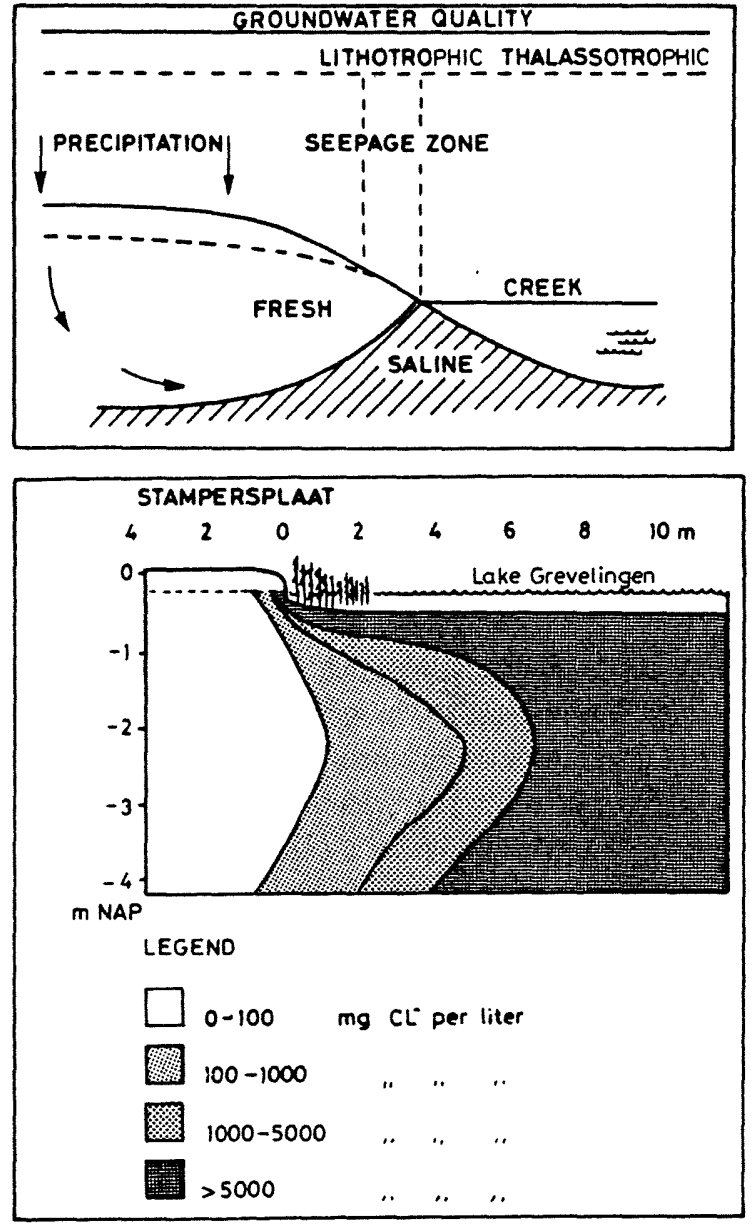

Fig. 4. (a) Hydrological processes in the borderzone along the western creek of the Braakman (after Smit \& Visser, 1987). (b) Isohalines in the border of the Stampersplaat (Grevelingen) and reed vegetation, indicating desalinized subsoil (loc. cit.).

this lake (the Lauwersmeer) is $2.30 \mathrm{~m}$, with large shallows and some deep areas down to $10 \mathrm{~m}$. About 300,000 ha of the mainland discharges on the Lauwersmeer. The water residence time in winter is only a few days, but in dry summer periods this may amount to several months. The saline waters have been replaced by eutrophic freshwater within a few months after enclosure.

The land surface comprises some higher saltmarshes and vegetated sedimentation fields (Dutch: landaanwinningsvakken) and a large surface of former tidal flats, 2100 ha of which are lower than $0.9 \mathrm{~m}$ above the average reservoir level.
Without means of local drainage this area remains a true wetland, of which the lower parts are occasionally flooded by the lake. The level can rise half a meter and more, especially in stormy periods, when the sea levels at low tide remain high and prevent the discharge of water through the sluices (Fig. 5). Areas below NAP $-1.20 \mathrm{~m}$ remain under water permanently and areas above NAP are almost never inundated, wheras the soils at NAP $-0.50 \mathrm{~m}$ are flooded several times a year.

After enclosure the banks of the lake are attacked by waves at only one height level. Much sand has been transported into the deeper parts of the lake and consequently in many places the shoreline retreats. The soil type of the drained flats varies from fine sands relatively poor in lutum (between $<3 \%$ to $3-5 \%$ ) and silty sands (5$12 \%$ lutum). The grain sizes of the sand fraction decrease with increasing lutum content. Sands predominate in the centre and the North; in the other directions the lutum content rises, reflecting the declining tidal influence.

In sandflats the groundwatertable follows the reservoir level providing that (a) the sands (poor in lutum) have a good permeability, (b) the subsoil is permeable and (c) the flats have no silty 'shoulders' along their borders. In the less permeable sands the groundwater in summer may descend far below the polder level, or rise to the soil surface, depending on precipitation and evapo-transpiration. The lack of lateral groundwater movements and the low pore volume of these soils cause quick saturation, after which the precipitation flows as surface run-off along the height gradient into the lake. This means a less effective desalination.

In the lower areas the poor desalination is even counteracted by the capillary rise of saline groundwater during periods of high evaporation. This wetland condition with (ground-) waterlevels up to the soil surface during longer periods of the year, is illustrated in Fig. 6. The hydrological regime is called dynamic mesoseries (after Drost $\&$ Visser, 1981). Sometimes the groundwater levels only descend a few $\mathrm{dm}$, e.g. under the influence of lateral supply of groundwater from higher areas; this situation, the stable mesoseries, offers 


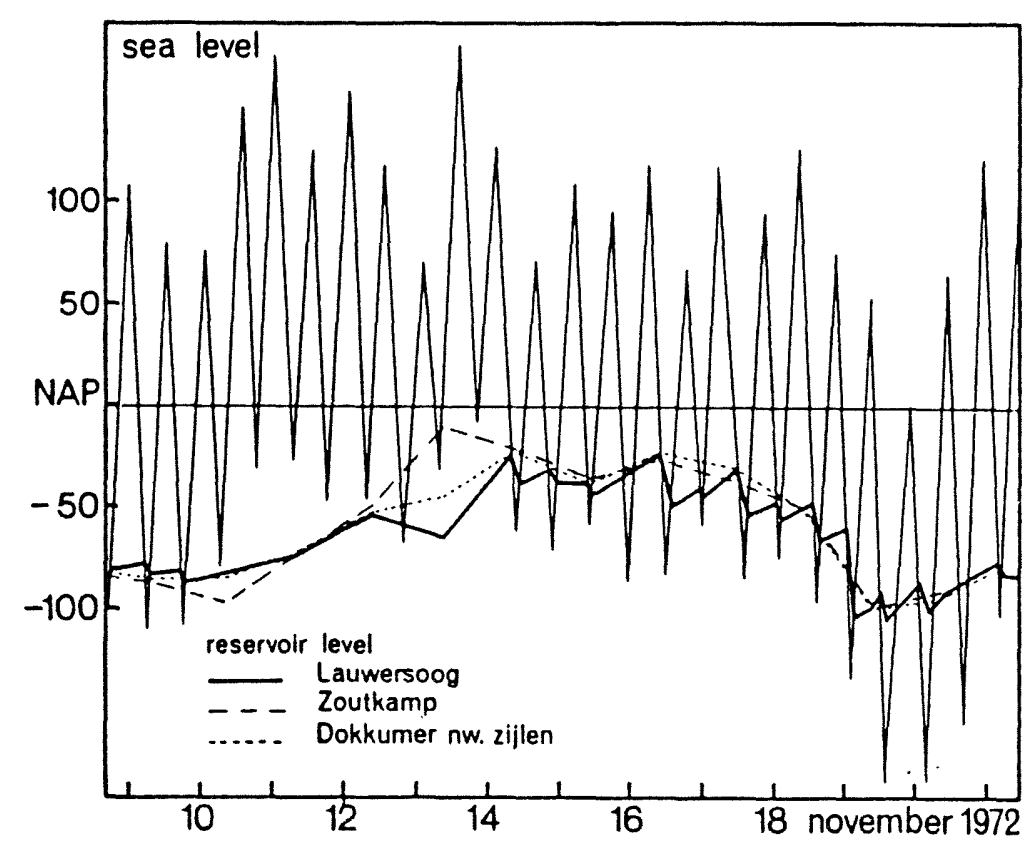

Fig. 5. The effect of a storm, 13 November 1972, on the water levels in the Lauwersmeer (Joenje, 1978).

a potential habitat for many interesting vegetation types and plant species from environments related to dune slacks.

The lime content of the soil varies from $2-3 \%$ in the sands to over $10 \%$ in the silty sands. As indicated earlier (Fig. 2), many other properties are correlated with the lutum content.

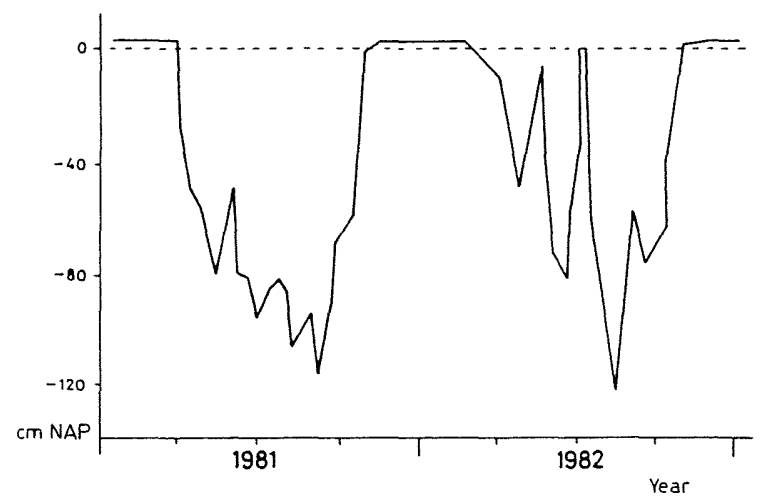

Fig. 6. The fluctuations of the groundwater level on a sandflat in the Lauwerszeepolder over a period of two years (dynamic mesoseries) (RIJP, 1985).

\section{Pioneer plant species}

The emerging new land presents a bare and salty environment. Only gradually, although in a few places rather quickly, the salt concentrations fall below 2 to $5 \mathrm{~g}$ per liter soil moisture (Fig. 7), at which levels several plant species from fresh environments can survive. Lethal salt concentrations may return occasionally, because of evapotranspiration. Plant colonization in the early years

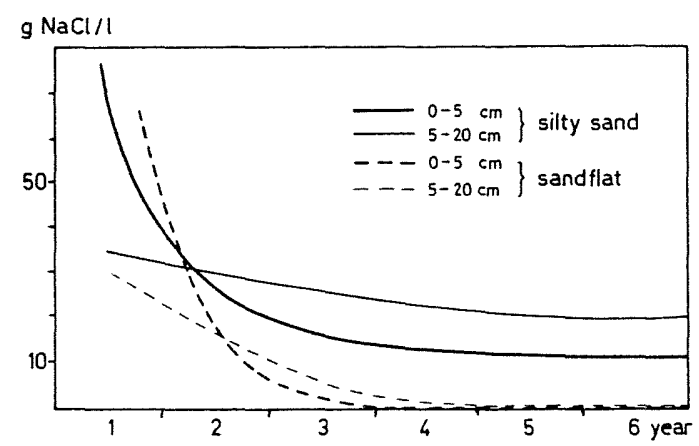

Fig. 7. Desalinizing upper soil layers of sand and silty sand in the Lauwerszeepolder during 6 years following the embankment. 
is almost exclusively by halophytes and halotolerant species and the duration of this first phase is strongly dependent upon the rate of desalination (most data from Joenje, 1978a).

At the time of the enclosure, in May, the seeds of these plant species growing on the saltmarshes of the former estuary, were already present in the soil, transported there by the tidal currents and in densities correlated (again) with the lutum content of the soil. The sandiest area in the centre and the North remained void the first year and with densities of the pioneer plants of the annual species of Salicornia brachystachya and $S$. dolychostachya, Suaeda maritima and Atriplex prostrata increasing in the direction of the surrounding marshes (Fig. 8).

This sparse pioneer vegetation only reached densities of about 4000 plants per ha, but they thrived well and consolidated their early estab- lishment by seeding the empty space successfully. Their seed dispersal was effected in the sheets of water blown across the saturated surface of the practically bare flats.

In the first year following embankment the hydrology and height level of the drained, saline surfaces barely influenced the colonization of the halophyte species, however this changed markedly in the following years. The populations of the annual halophytes demonstrated an exponential increase during the first four years, until they reached very high densities which caused competitive interactions between individuals. Exponential increase of biomass was also stopped by competition with newly arriving species (Fig. 9). Several species of halophytes, notably Spergularia salina, Aster tripolium and several species of Puccinellia (P.maritima, P.cappillaris, P. distans ssp. distans, $P$. d. ssp. borealis) had to start from

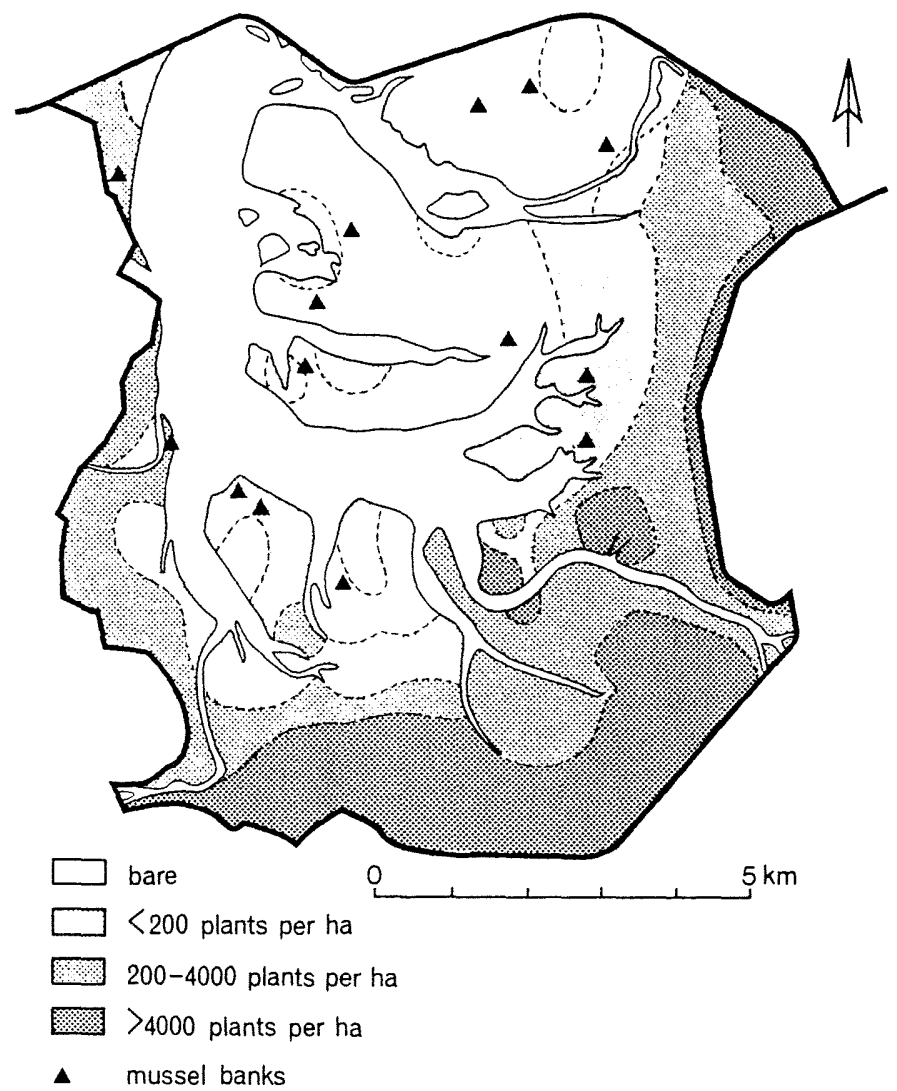

Fig. 8. The density of the pioneer vegetation the first year of the Lauwerszeepolder. 


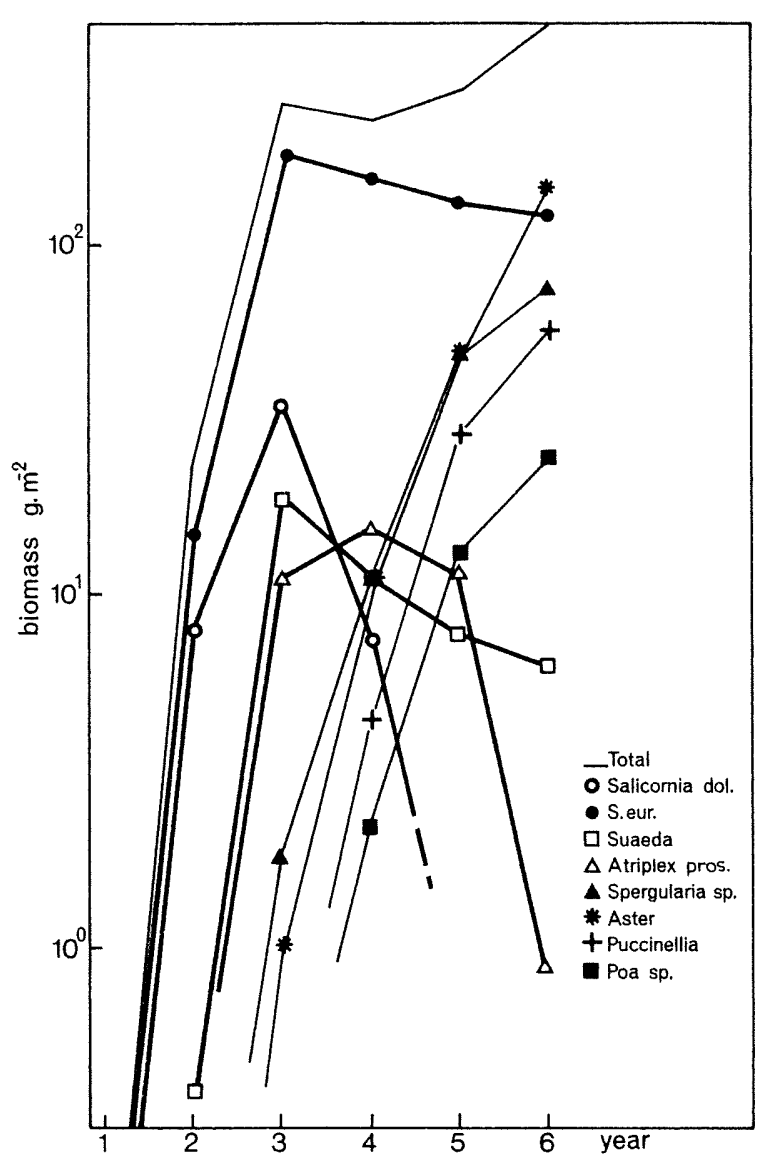

Fig. 9. The rise of the principal colonizing species in the first 6 years of the Lauwerszeepolder. a few individuals (lack of a seed bank) or had to migrate in from the saltmarshes. Arriving much later, these species were equally able to increase their numbers exponentially, although the area was already densely occupied by the first invaders, notably the Salicornia spp. (Fig. 9).

The colonization by salt-tolerant species producing the characteristic patterns of seedling aggregates around the parent plants, was followed by the increasing dominance of perennial species (notably Aster tripolium, Puccinellia spp., Spergularia maritima, Poa trivialis). After 7 years the annual halophytes began to give way to a natural grassland vegetation, which in following years often became dominated by Agrostis stolonifera and Phragmites australis.

The foregoing description of the colonization as summarized in Fig. 9, parallels the qualitative descriptions given by Feekes for the Wieringermeer-polder (Feekes, 1936) and for the sandflats along the friesian coast of the IJsselmeer (Feekes. 1943). The colonization of the sandier Middelplaten in the Lake Veere (Beeftink et al. 1971) shows essentially the same pattern of "come and go' with partly the same species (Fig. 10).

Apparently, where desalination proceeds over a period of several years, an orderly series of species waves occurs. By contrast, the plant col-

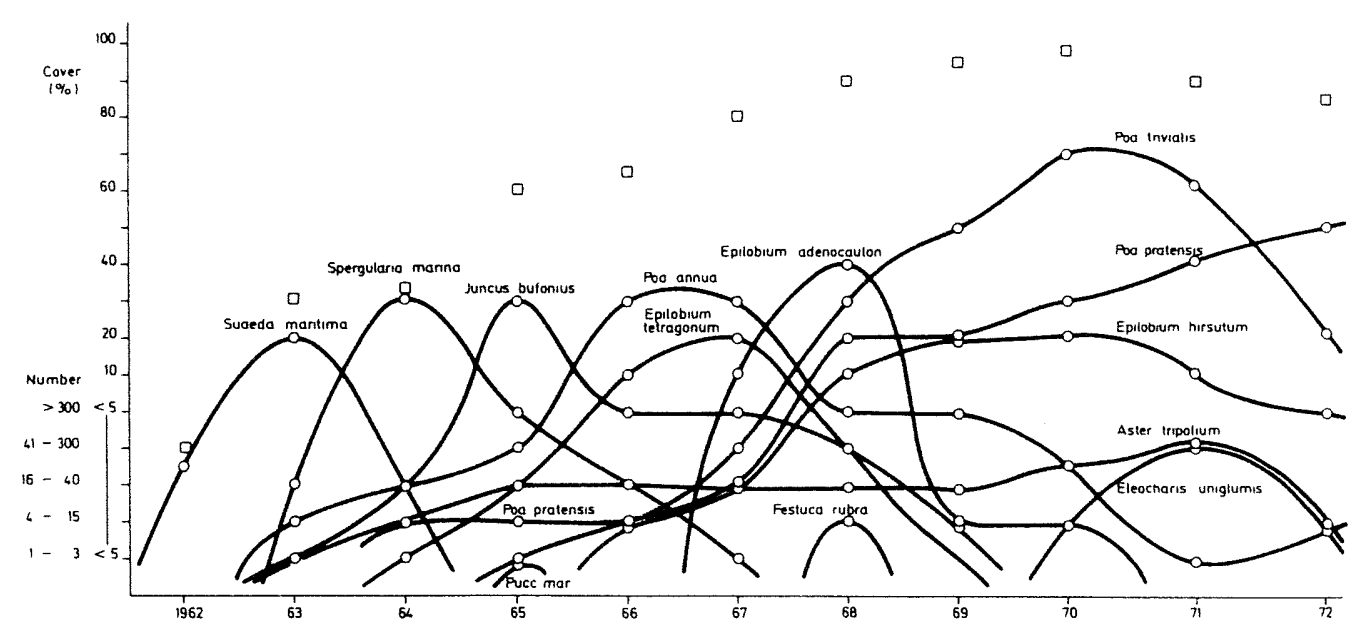

Fig. 10. Population dynamics of the principal species in a permanent quadrat on the Middelplaten, Veerse Meer (after Beeftink et al., 1971). 
onization of more quickly desalinizing musselbanks and former sedimentation fields, all silty and well-drained, proceeded capriciously and quickly. On isolated musselbanks 38 species of vascular plants were already present in the first year; apart from halophytes, common weeds from the surrounding mainland predominated, either with hard-scaled seeds (seeds of Rumex, Polygonum, Chenopodium a.o. apparently survived the marine conditions, being deposited before the enclosure), or arriving by air in the first year (species of Chamaerion, Epilobium, Tussilago, Sonchus, Cirsium and Senecio).

Within a few years perennial ruderal species came to dominate and the resulting dense and highly productive vegetation consisted of Epilobium hirsutum, Chamaerion angustifolium, Urtica dioica, Cirsium arvense and several grass species. This succession series is well-known from similar areas after embankment, e.g. in the southwest of the Netherlands (Slikken van Flakkee, Markiezaatsmeer) and in the new polders of the German Bight. The musselbanks and other small areas rapidly colonized by a glycophyte vegetation formed the centres from which later desalinizing places were effectively colonized.

\section{Fauna}

As with the plants, several animal species display a widespread, temporary dominance and some of them developed huge populations or 'plagues,' a most typical feature of early stages of succession. The vole population in the former saltmarsh increased and threatened the crop on the adjacent mainland, but also attracted many birds of prey, notably Short-eared Owl, species of Harriers and Buzzards. Several waves of Chironomid midges, a plague of noctuid caterpillars and mass occurrence of several species of beetles and spiders are reported (Meijer 1980). Most significant and striking however, were the high numbers of geese and ducks (Barnacle Goose, Wigeon, Teal etc.), attracted by the annual halophyte vegetation. The waterfowl harvested almost all the ears from Salicornia by stripping them off, even anticipating the crop in their arrival date (Fig. 11; Van Eerden, 1981).

Salicornia plants on the desalinizing flats contained less salt than in marine condition $\vec{s}$, where they normally are not grazed.

The in winter saturated surface offered ideal conditions for Teal to sieve the seeds of Salicornia and Spergularia spp. from the silty puddles on a large scale. In later years Grey-lag Geese were observed destroying the soggy mat of Agrostis stolonifera, by trampling and digging for rhizomes and for the tubers of Triglochin palustris.

\section{Vegetation succession on the sandfats}

Whereas the annual halophytes occupied both the higher and lower flats, the subsequent invaders were each confined to one of the three main habitat types: the lower flats (silty, rather persistently saline and waterlogged and/or flooded in winter), the flats out of reach of most inundations by the

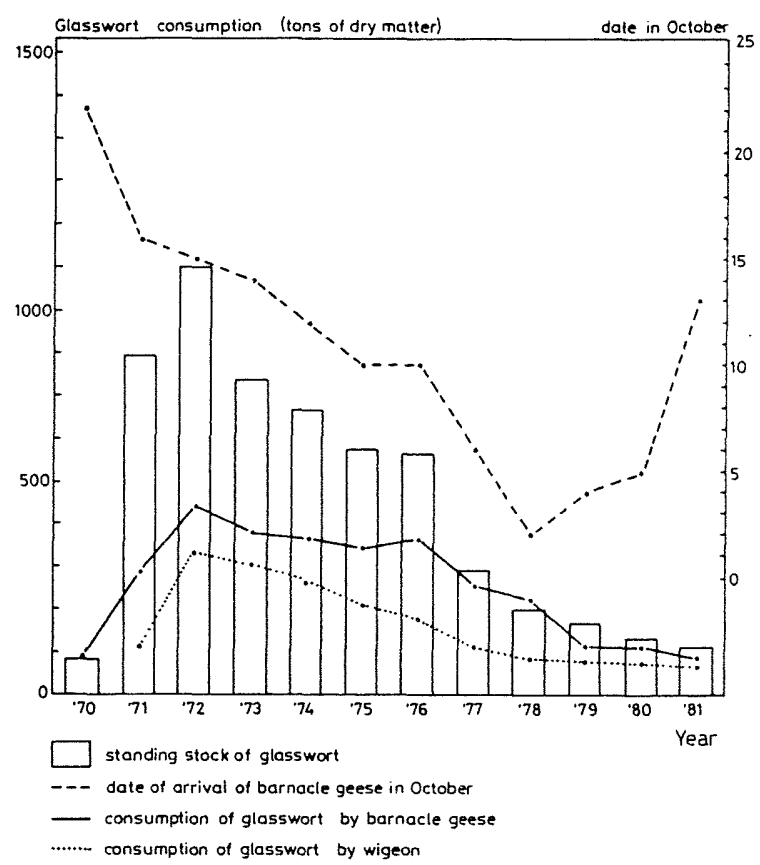

Fig. 11. Consumption of Salicornia seeds by Barnacle Goose and Wigeon in the Lauwerszeepolder, together with the dates of arrival of the geese, over a period of 12 years (after $V$ an Eerden, 1985). 
lake (still brackish with impeded drainage) and the higher sandflats (quickly desalinized and with a lower water table).

The silty sands after 8 years harboured a saltmarsh-like vegetation with species as $\mathrm{Pucci}$ nellia maritima, Triglochin maritima, Juncus gerardii, Carex extensa, Plantago maritima; even species such as Glaux maritima, Halimione portulacoides and Limonium vulgare were occasionally found. After 6 to 8 years the less salt-tolerant species like Agrostis stolonifera and Alopecurus geniculatus gradually gained importance (Table 1 ).

The sandflats had attracted several species from dune slack-type environments, such as Carex oederi pulchella, $C$. distans, Centaurium pulchellum, C. littorale, Odontites verna serotina, Parnassia palustris and Schoenus nigricans (Bruinenberg et al., 1980) (Table 1).

The higher situated and well-drained sands showed an early development of Bryophytes (Bryum bicolor, Funaria hygrometrica a.o., viz. Joenje \& During, 1977), followed by many euchorous phanerogams from fresh habitats like
Epilobium spp., Erigeron canadense, Senecio vulgaris etc., but also Reed and Willows were among the successful invaders (Table 1). Calamagrostis epigejos, Hippophae rhamnoides, Festuca rubra, Carex arenaria readily colonized this nutrientpoor and in some periods very dry habitat (xeroseries). This dry area occupying a few tens of ha, is stricktly speaking not a wetland, but forms the upper part of the characteristic soil- and height gradient of the type 'limes divergens' (Van Leeuwen, 1966), a prerequisite milieu for botanical developments towards stable communities with rare and less common species.

\section{Successional trends}

The successional trends, arising from the establishments described, are towards Junco-Moliniontype vegetation on the high sands and LolioCynosuretum-type vegetation on the siltier and moist or flooded areas, as well as towards many transitions. The development is illustrated in the

Table 1. Groups of plant species characterizing the three main habitat types (xero-, dynamic meso-, and stable mesoseries) of the flats in the Lauwerszeepolder after 8 years; silty sands reflect saline conditions.

\begin{tabular}{|c|c|c|}
\hline $\begin{array}{l}\text { Dry sandflat } \\
\text { (xeroseries) }\end{array}$ & $\begin{array}{l}\text { Sandflat } \\
\text { (d-mesoseries) }\end{array}$ & $\begin{array}{l}\text { Silty sands } \\
(s-\text { mesoseries) }\end{array}$ \\
\hline Cerastium fontanum & Agrostis stolonifera & Agrostis stolonifera \\
\hline Cirsium arvense & Alopecurus geniculatus & Armeria maritima \\
\hline C. vulgare & Calamagrostis epigejos & Artemisia maritima \\
\hline Erigeron canadense & Carex arenaria & Carex extensa \\
\hline Epilobium adnatum & C. distans & Glaux maritima \\
\hline E. parviflorum & C. serotina pulchella & Halimione portulacoides \\
\hline E. adenocaulon & C. pulchellum & Limonium vulgare \\
\hline Phragmites australis & Hippophae rhamnoides & Juncus gerardii \\
\hline Senecio vulgaris & Juncus alpino-articulatus ssp. atricapillus & Plantago maritima \\
\hline S. arvensis & Juncus maritimus & Spergularia media \\
\hline Taraxacum sp. & Odontites verna ssp. serotina & Triglochin maritima \\
\hline Juncus bufonius & Parapholis strigosa & \\
\hline Salix alba & Parnassia palustris & \\
\hline \multirow[t]{7}{*}{ S. viminalis } & Plantago coronopus & \\
\hline & Rubus caesius & \\
\hline & Sagina nodosa & \\
\hline & S. maritima & \\
\hline & Salix arenaria & \\
\hline & Schoenus nigricans & \\
\hline & Senecio jacobaea & \\
\hline
\end{tabular}


Table 2. Plant species found after 8 years, indicating a trend towards Junco-Molinion- (nutrient-poor sands) or LolioPotentillion- (water meadow) type communities.

\begin{tabular}{ll}
\hline Species of Lolio-Potentillion & Species of Junco-Molinion \\
\hline Agrostos stolonifera & Agrostis capillaris \\
Alopecurus geniculatus & Agrostis canina \\
Angelica silvestris & Anthoxanthum odoratum \\
Anthriscus silvestris & Calamagrostis canescens \\
Bidens tripartitus & Cerastium glomeratum \\
Cardamine pratensis & Cirsium palustre \\
Cicuta virosa & Eriophorum angustifolium \\
Eupatorium cannabinum & Festuca ovina ssp. tenuifolia \\
Lycopus europaeus & Hieracium pilosella \\
Lythrum salicaria & Holcus lanatus \\
Lychnis flos-cuculi & Hypochaeris radicata \\
Mentha aquatica & Juncus articulatus \\
Phalaris arundinacea & J. effusus \\
Potentilla anserina & J. conglomeratus \\
Rumex acetosa & Luzula campestris \\
R. crispus & Poa pratensis \\
Sium erectum & Rumex acetosella \\
S. latifolium & \\
Solanum dulcamara & \\
Stachys palustris & \\
Valeriana dioica & \\
\hline
\end{tabular}

species lists, given in Table 2. After a decade the uppermost soil layer of the high sands has already lost part of its Calcium carbonate by leaching, a process which continues together with the lowering of the $\mathrm{pH}$ and the accumulation of humus and nutrients in the upper soil layer (Joenje, 1978a). Decalcification processes in marine sediments are discussed by Verhoeven (1962).

On the silty sands, by contrast, the succession shows an extensive spread of Agrostis stolonifera, followed by a gradually thickening stand of Reed, often together with Salix spp. (notably Salix repens and in higher places $S$. alba, $S$, viminalis a.o.). Comparing this case with some older areas (e.g. the sandflats on the friesian westcoast of the IJsselmeer (Slager \& Smit, 1987)), it can be concluded, that the syntaxa mentioned above will only gradually become saturated with their "characteristic' species. The number of species could rise considerably, provided that the biomass of the dominants mentioned is removed periodically by some kind of management or 'nature exploitation', be it grazing, mowing or even turf cutting or an occasional controlled burn. This effect of the removal of the biomass, well-known in Dutch nature management practice and often discussed scientifically (e.g. Grime, 1979), makes it a crucial measure in most of the management schemes applied in the new polder nature reserves. Under the next heading the various activities applied in different polders will be considered, together with the prevailing ecosystem characteristics.

\section{Perspectives for maintenance and management}

With respect to the general parameters of an ecosystem - the biomass-, energy- and nutrient flows - the new wetlands cannot be taken as isolated areas. Indeed the low lying grounds are often directly influenced or inundated by nutrient-rich adjacent waters linking the system to an often large agricultural hinterland. The waters (reservoirs) then tend to eutrophicate (Berger, 1985). The lower and mostly silty grounds may also receive (excess) nutrients from inundation waters. They may remain saline for a period of several decades because of impeded drainage.

As long as there is no surface drainage system, the low grounds are characterized by a groundwater-table of the hygroseries- or stable mesoseries-type (Fig. 12). This environment is to be regarded as a proper wetland condition. The higher and drier (sandier) grounds, well out of reach of inundations, have the groundwater regime of the xeroseries.

The two environments mentioned are mostly linked by characteristic soil- and height transitions, either steep or gradual, reflecting the tidal origin of the landscape and also presenting a most valuable abiotic base for natural succession towards stable and species-rich communities. It follows, that developments in the area and the value as a nature area have to be judged within this landscape- and ecological context.

The lower area, base- and nutrient-rich, and the higher sands where leaching prevails, follow different successional series. The environmental dynamics in the lower zone (deposits of debris. 


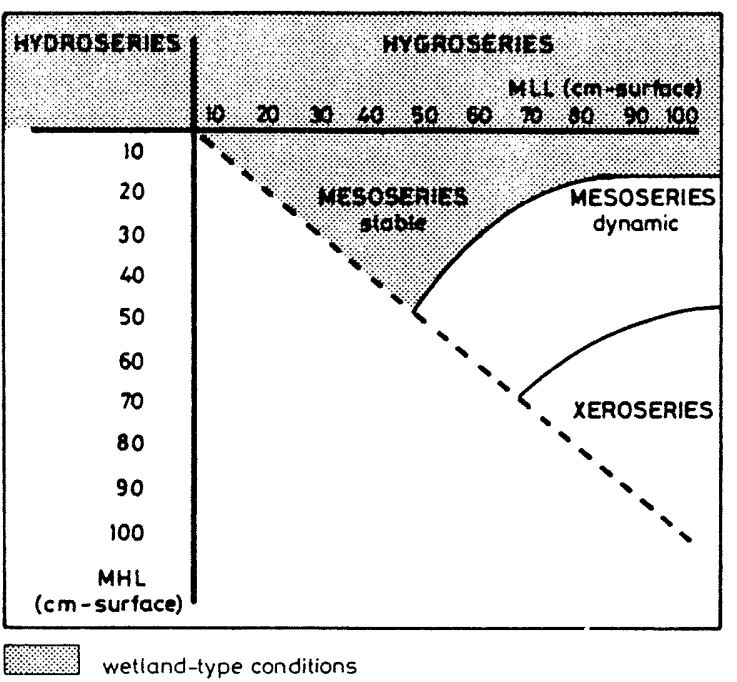

Fig. 12. The relation between (hygro-, meso- and xero-)series and the average shallowest groundwater level (after Smit \& Visser, 1987). The hatched area represents wetland condition (MHL: mean highest level; MLL: mean lowest level).

silt, icesheets) and the changes in (ground)water levels sustain a considerable annual production by a coarse vegetation of Reed and Willows, the debris of which is accumulating. This development is found in the Lauwerszeepolder, on the Wadden-islands, along the Amstelmeer, along the borderlakes of the IJsselmeer-embankments, as well as in the Delta region.

An older example is found on the sandflats along the friesian coast of the IJsselmeer. In Fig. 13 a transect of the Piamer Kooiwaard, a sandflat, is depicted. Here, after some 50 years a 'laissez-faire' management has produced a Phragmites, Scirpus maritimus and Salix wilderness poor in species. A distinct peat deposit is found on the intermediate level of the height gradient, which is above most inundations. Here the influence of precipitation prevails and acid conditions develop, in which Eriophorum angustifolium is found and Sphagnum increases. Since the start of a mowing regime and after the removal of the willowtrees, a species-rich meadow vegetation has developed along the height gradient, gradually replacing the Phragmition communities. By now 180 species of vascular plants with e.g. Carex tumidicarpa, C. lasiocarpa, C. diandra, Dactylorhiza majalis and Pedicularis palustris, and, slightly higher, Rhinanthus angustifolius, Lychnis flos-cuculi, are reported (Slager \& Smit, 1987; viz. also Feekes, 1943). Still a halophyte vegetation persists in some depressions, with Puccinellia maritima, $P$. distans, Juncus gerardii, Triglochin maritima, Glaux maritima and Parapholis strigosa (compare Tables 1 and 2). This resilient saline

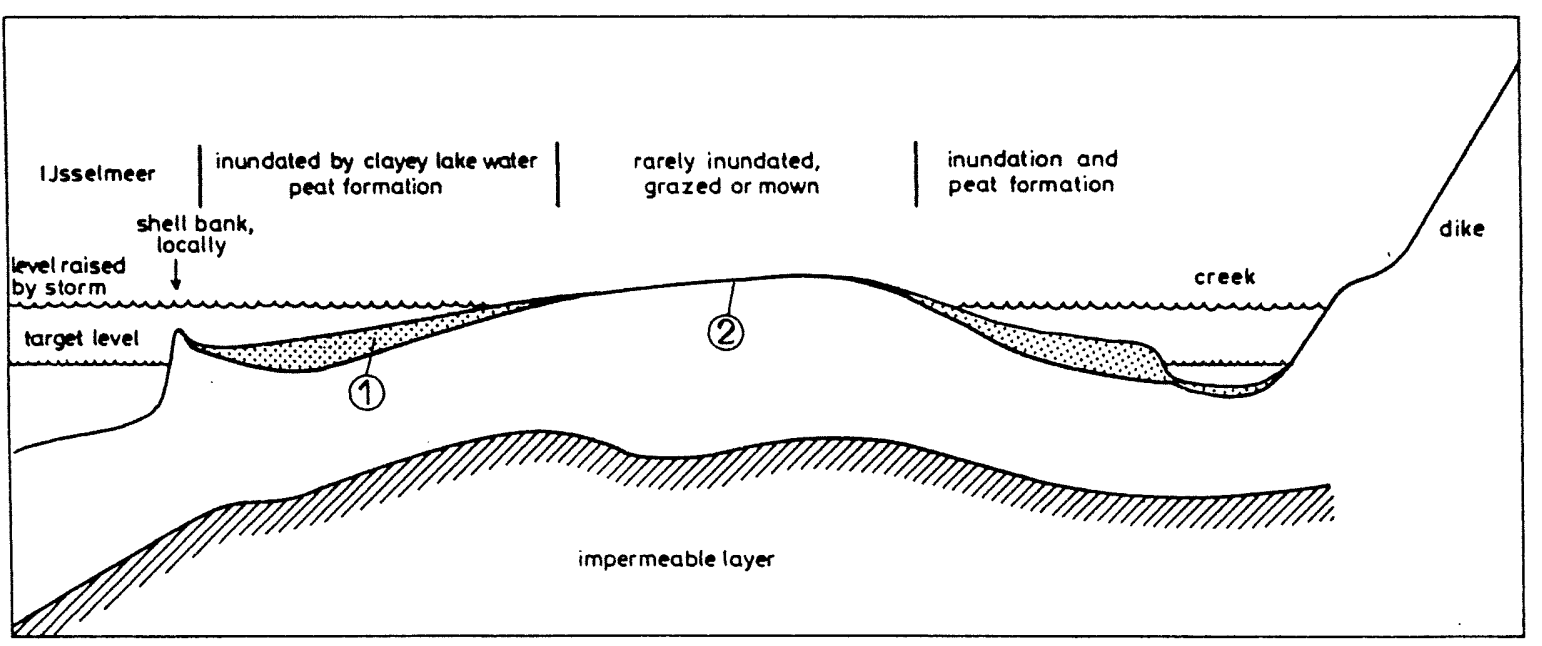

Fig. 13. The hydrological zones in the Piamer Kooiwaard (after Slager \& Smit, 1987). (1) Vegetation of Phragmites, Scirpus maritimus and Willows. (2) Grassland locally rich in species. 
element resembles that described by Westhoff (1969) for permanent quadrats in the marshes of the former Zuiderzee.

A very interesting example of these successional transitions is reported from Denmark (Gravesen, 1972) in the area Tipperne of the Ringkøping fjord, as a result of the partial removal of the marine influences. Furthermore, the brackish to fresh conditions along the coasts of the Baltic create numerous locations with quite similar vegetation types (Gillner, 1960, Wallentinus, 1973).

The land use or nature management most often applied, is extensive grazing by cattle and horses; sheep are vulnerable in these areas since they tend to become infested by the liver fluke. The large areas even make it a profitable use (Lauwerszeepolder, Grevelingen). It not only restores and maintains the ecological conditions for smaller and less competitive plant species (open sward, locally saline), but it also keeps the vegetation accessible as a feeding ground for geese and other waterfowl and wintering waders, as well as providing the breeding biotopes for meadowbirds (Van Eerden, 1985; Joenje, 1981).

Experimental management of these new landscapes has been tried out not only in the Netherlands, but also in Great Britain, Germany and Denmark. Indeed, the results are difficult to compare in view of the various activities and the (phyto) geographical differences.

\section{Threats}

Finally, one factor common to all these new or still young nature areas has to be stressed as the most crucial for retaining their value as natural wetland communities. This is the groundwater regime, the (stable) mesoseries, in relation to the level of the surface (reservoir) waters; preferably, though not necessarily, occasional inundations should occur in the winter half of the year.

Whether it is recreation, military training or agriculture, almost every activity on these areas involves drainage or other alterations to water regimes. Thus we may conclude that in order to develop nature conservation interests in a wetland perspective,

- the management of the water level fluctuations, preferably lower summer and higher winter levels, has to be controlled and consistent and

- no surface drainage system should be imposed.

\section{References}

Bakker, D., 1958. Over de betekenis van stikstof voor de natuurlijke vegetatie der IJsselmeerpolders. Van Zee tot Land 26: 53-66.

Beeftink, W.G., 1975. The ecological significance of embankment and drainage with respect to the vegetation of the southwest Netherlands. J. Ecol. 63: 423-458.

Beeftink, W.G., M.C. Daane \& W. de Munck, 1971. Tien jaaroecologische verkenningen langs het Veerse Meer. Natuur enLandschap 25: 50-63.

Berger, C., 1985. Hydrobiologische aspecten van het Lauwersmeer. In: RIJP, Vijftien jaar afgesloten Lauwerszee. Lelystad: 117-125.

Bruinenberg, J., W. Joenje \& T. Wierenga, 1980. Hapaxanth species of coastal beach plains colonizing embanked sandflats. Acta Bot. Neerl. 29: 497-508.

Drost, H.J. \& J. Visser, 1981. Het grondwaterregime als structurerende factor voor de begroeiing in afgesloten estuaria met een toepassing in het Grevelingenbekken. Flevobericht 163: 201-207. Rijksdienst voor de IJsselmeerpolders. Lelystad.

Feekes, W., 1936. De ontwikkeling van de natuurlijke vegetatie in de Wieringermeerpolder, de eerste groote droogmakerij van de Zuiderzee. PhD. Thesis, Wageningen.

Feekes, W., 1943. De Piamer Kooiwaard en Makkumerwaard. Ned. Kruidk. Arch. 53: 288-331.

Gilliner, V., 1960. Vegetations- und Standortsuntersuchungen in den Strandwiesen der Schwedischen Westkuste. Acta Phytogeographica Suec. 43: 1-98.

Gravesen, P., 1972. Plant communities of saltmarsh origin at Tipperne, Western Jutland. Bot. Tydsskr. 67: 1-32.

Grime, J.P., 1979. Plant strategies and vegetation processes. John Wiley \& Sons, Chichester.

Joenje, W., 1978. Plant colonization and succession on embanked sandflats. PhD. Thesis, Groningen.

Joenje, W., 19\$2. Nature in new Wadden-polders: conservation by exploitation. In: Polders of the World. ILRI. Wageningen.

Joenje, W. \& H.J. During, 1977. Colonisation of a desalinating Waddenpolder by bryophytes. Vegetatio 35: $177-$ 185.

Meijer, J., 1980. Colonization of the Lauwerszeepolder by some elements of the arthropod fauna. PhD. Thesis, $\mathrm{VL}$ Amsterdam.

Pot, R., 1983. Ontziltingsgeschiedenis van enkele oevers in de 
Lauwerszeepolder. Report Dept. Plant Ecology, State Univ. Groningen.

Schultz, F. 1987, In: J.J. Vonk \& R.T. de Boer, 1989. Inleiding tot de inrichting van het Landelijke gebied. Pudoc, Wageningen.

Slager, H. \& G.F.J. Smit, 1987. De Waarden langs de friese IJsselmeerkust: samenhang tussen bodem, hydrologie en vegetatie. Landschap 4: 264-273.

Smit, G.F.J. \& J. Visser, 1987. De samenhang tussen bodem, hydrologie en vegetatie in het Veerse Meer en de Braakman. Landschap 4: 274-288.

Van der Meijden, R., E.J. Weeda, F.A.C.B. Adema \& G.J. de Joncheere, 1988. Flora van Nederland. WoltersNoordhoff, Groningen.

Van Eerden, M.R., 1985. Aspecten van de ontwikkeling van de Vogelbevolking. In: RIJP, Vijftien jaar afgesloten Lauwerszee. Resultaten van onderzoek en ervaringen met inrichting en beheer. Flevobericht 247: 145-172. Rijksdienst voor de IJsselmeerpolders, Lelystad.

Van Schreven, D.A., 1965. Stikstofomzettingen in jonge IJsselmeerpolder gronden. Van Zee tot Land 41, Tjeenk Will- ink, Zwolle.Verhoeven, B., 1952. Embankment and cultivation of marine foreland. Soil Science 74: 91-95.

Verhoeven, B., 1952. Embankment and cultivation of marine foreland. Soil Science 74: 91-95.

Verhoeven, B., 1963. On the calciumcarbonate content of young marine sediments. Bull. Intern. Inst. Land Reclamation and Improvement 4: 6-27.

Visser, J., G.J. Rook \& D.J. Fluijt, 1985. Ontziltings- en verziltingsprocessen op de oevers van het Grevelingenmeer. Landschap 2: 226-234.

Wallentinus, H.G., 1973. Above ground primary production of a Juncetum gerardii on a Baltic seashore meadow. Oikos 24: $200-219$

Westhoff, V., 1969. Langjährige Beobachtungen an Aussüszungs- Dauerprobeflächen beweideter und unbeweideter Vegetation an der ehemahligen Zuiderzee. In R. Tüxen (ed.) Experimentelle Pflanzensoziologie. Dr W. Junk Publishers, The Hague: 246-255.

Zuur, A.J., 1961. Initiele bodemvorming bij mariene gronden. Med. van de Landbouwhogesch. en de Opzoekingsstations van de Staat te Gent 24: 7-33. 